\title{
A reappraisal of polymyxin $B$ dosing based on population pharmacokinetic model in patient with renal insufficiency
}

Xuben $\mathrm{Yu}^{1}$, Chunhong Zhang ${ }^{1}$, Jingye Pan $^{1}$, Ying Dai $^{1}$, Ziye Zhou ${ }^{1}$, Fan Yang ${ }^{3}$, Ruolan Sun ${ }^{3}$, Yexuan Wang ${ }^{3}$, Yancheng $\mathrm{Cao}^{3}$, Changcheng Sheng ${ }^{4}$, Zheng Jiao $^{2 *}$, Guanyang Lin ${ }^{1 *}$

${ }^{1}$ Department of Pharmacy, the First Affiliated Hospital of Wenzhou Medical University, Wenzhou, China.

${ }^{2}$ Department of Pharmacy, Shanghai Chest Hospital, Shanghai Jiao Tong University, Shanghai, China.

${ }^{3}$ Department of Pharmacy, Wenzhou Medical University, Wenzhou, China.

${ }^{4}$ Department of Pharmacy, Huashan Hospital, Fudan University, Shanghai, China.

${ }^{3}$ Department of Pharmacy, Wenzhou Medical University, Wenzhou, China.

X.Y., C.Z. and J.P. contributed equally to this work.

Corresponding author: *Address correspondence to: Guanyang Lin and Zheng Jiao

Tel: +86-577-55578706, Fax: +86-557-55578706

E-mail: 13867702133@163.com to G.L., jiaozhen128@hotmail.com to Z.J. 


\section{Abstract}

Background. Current FDA-approved label recommends polymyxin B dosing should be adjusted according to renal function, despite several studies proved poor correlation between polymyxin B PK and creatinine clearance. The study aims to assess the impact of renal function on polymyxin B metabolism and identify an alternate dosing strategy by population analysis.

Methods. Blood samples from adult patients were collected at steady state during routine therapeutic drug monitoring. Nonlinear mixed effects modeling was employed to build a population PK model of polymyxin B. Monte Carlo simulations were performed to design polymyxin B dosing regimens across various renal function.

Results. Pharmacokinetic analyses included 112 polymyxin B concentrations at steady state from 32 adult patients aged 37-93 received intravenous polymyxin $B(100-200 \mathrm{mg} / \mathrm{d})$. The creatinine clearance in patients was 5.91-244 mL/min. In the final population $\mathrm{PK}$ model, $\mathrm{CrCL}$ was the significant covariate on $\mathrm{CL}$ (typical value, $1.59 \mathrm{~L} / \mathrm{hr}$; between-subject variability, 13\%). Mean (SD) individual empirical Bayesian estimates of $\mathrm{CL}$ was $1.75(0.43) \mathrm{L} / \mathrm{hr}$. A new dosing strategy combining the PK/PD targets and Monte Carlo simulation indicated that polymyxin $B$ dose reductions improved the probability of achieving optimal exposures in simulated patients with renal insufficiency. For severe infections caused by organisms with $\mathrm{MIC}$ of $\geq 2 \mathrm{mg} / \mathrm{L}$, though a high daily dose (e.g. $200 \mathrm{mg} /$ day) would possible for bacterial eradication, the risk of nephrotoxicity is significantly increased.

Conclusion. A population PK model was established to develop individualized polymyxin B dosage regimens that the dose of polymyxin B should be adjusted according to CrCL.

Keywords. polymyxin B; pharmacokinetics; dose individualization 
medRxiv preprint doi: https://doi.org/10.1101/2020.01.24.20018481; this version posted January 28, 2020. The copyright holder for this preprint (which was not certified by peer review) is the author/funder, who has granted medRxiv a license to display the preprint in perpetuity.

All rights reserved. No reuse allowed without permission.

\section{Introduction}

Polymyxins (polymyxin B and colistin) become available clinically in the $1950 \mathrm{~s}$ to treat Gram-negative bacterial infections. However, they were fell out of favor in 1970 s due to the narrow therapeutic window and their potential to cause nephrotoxicity and neurotoxicity $[1,2]$. Over the last decade, polymyxins are again being used due to the emergence of multidrug-resistant (MDR) Gram-negative bacteria, combined with a paucity of new antibiotics [3-6].

Polymyxins, include polymyxin B and polymyxin E (colistin), are available for clinical use. Colistin is administered parenterally in the form of an inactive prodrug (colistin methanesulfonate, CMS) [7]. In contrast, polymyxin B is administered parenterally as its active form, which leads to less complex pharmacokinetics. Therefore, polymyxin B has been increasingly used due to its active form and potentially less nephrotoxic than colistin $[8,9]$.

The clinical PK/PD of polymyxin B are scarce. Only a very small number of studies have examined the pharmacokinetics of polymyxin B following parenteral administration in human. Polymyxin B is not absorbed from the normal alimentary tract. The drug is excreted slowly by the kidneys. Its tissue diffusion is poor and the drug does not pass the blood brain barrier into cerebrospinal fluid. It should be noted that the PK data in the product information of polymyxin B for injection were obtained from studies conducted more than 40 years ago. The recent studies focused on PK analysis of polymyxin B pointed out that it was not significantly eliminated by the kidney and polymyxin B total body clearance was poorly correlated with creatinine clearance [10-11]. Therefore, the dosage of polymyxin B was not necessarily to be adjusted in patients with renal insufficiency according to the PK rationale [12]. However, current FDA-approved prescribing information recommends dose reducing "downward for individuals with renal insufficiency" [13], but the specific dosing strategy for patients with renal insufficiency is not provided by the package inserts. Although the recent reports on the PK of polymyxin B refute this recommendation, these studies were limited with a small number of 
samples. Therefore, larger PK studies in patients with renal insufficiency are needed to validate the recommendations provided by the package insert for polymyxin B and optimize its clinical use in patients with renal insufficiency. In the current study, we aim to identify the impact of patient renal function on polymyxin B metabolism and determine pragmatic dose modifications for patients with renal insufficiency using real-world data from routine therapeutic drug monitoring (TDM).

\section{Patients and Methods}

\section{Patients and Ethics.}

The study was approved by the Ethical Committees of the First Affiliated Hospital of Wenzhou Medical University ([2019]034), China. From June 2018 to May 2019, adult patients ( $\geq 18$ years) treated with intravenous polymyxin $B$ for more than 48 hours with at least one steady-state polymyxin B serum concentration measured were included. Patients who died within 24 hours after the use of polymyxin B were excluded from this study. The consent were free passed by Ethics Committee in Clinical Research ( ECCR ) of the First Affiliated Hospital of Wenzhou Medical University.

\section{Data sources.}

Polymyxin B PK data were obtained retrospectively from a database maintained at the Department of Pharmacy reflecting routine clinical TDM in 32 patients (aged $\geq 18$ years) treated at the First Affiliated Hospital of Wenzhou Medical University. Per protocol, blood samples were collected after $\geq 48$ hours of treatment with polymyxin B (polymyxin B sulfate; for Injection). Polymyxin B $\mathrm{C}_{\max }$ is obtained 30 minutes after the end of intravenous infusion, while $\mathrm{C}_{\min }$ is obtained 30 minutes prior to the next dose. Dates and exact time of polymyxin $B$ treatment and TDM were able to be indexed. The quantification of plasma 
medRxiv preprint doi: https://doi.org/10.1101/2020.01.24.20018481; this version posted January 28, 2020. The copyright holder for this preprint (which was not certified by peer review) is the author/funder, who has granted medRxiv a license to display the preprint in perpetuity.

All rights reserved. No reuse allowed without permission.

concentration was performed using a validated high performance liquid chromatography-tandem mass spectrometry (LC-MS/MS) assay [14]. Intraand inter-day assay coefficients of variation were $<10 \%$ and the lower limit of quantification was $0.1 \mathrm{mg} / \mathrm{L}$. Demographic data, intensive care unit admission, serum creatinine measurements, and other laboratory values were available in the database. Estimated creatinine clearance was calculated using the Cockcroft-Gault equation. Data organization and visualization was performed using R (version 3.6.0) and R Studio (version 1.2.1335).

\section{Pharmacokinetic Analysis}

Population PK analysis was performed using non-linear mixed-effects modeling in NONMEM (version 7.4, Icon Development Solutions, Ellicott City, MD, USA) implemented using Pirana (version 2.9.7). R (version 3.6.0) and Xpose (version 4.3.2) software packages were used to generate diagnostic plots. The first-ordered conditional estimation method with inter- and intra-subject variability was used throughout the model development process.

One- and two-compartment models were explored for the polymyxin B serum concentration-time profiles with linear or nonlinear elimination. Fixed effects were parameterized in terms of $\mathrm{CL}$ and V. Between-subject variability (BSV) was modeled using exponential function. Residual variability was assessed using additive, proportional, and combined (additive plus proportional) error models. The base model was selected based on the Akaike Information Criteria (AIC) and visual inspection of diagnostic plots.

Exploratory analysis was performed before covariate modeling to examine the distribution of covariates in the population as well as correlation between covariates of interest. Primary covariates included demographics (age, sex), body size (total body weight $[\mathrm{TBW}]$ ), creatinine clearance $(\mathrm{CrCL})$, serum albumin concentration. Relationships between individual empirical Bayesian estimates of PK parameters and patient covariates were examined visually. Covariates were included using a forward selection process with a threshold 
decrease in OFV of 3.84 ( $p<0.05,1$ degree of freedom [df]) until no further decrease in OFV was observed. In backward elimination, the covariate was retained in the final model with a threshold increase in OFV of $6.63(p<0.01,1$ df), otherwise, it was eliminated from the model. The additional criterion for retaining the covariate in the final model was a decrease in the unexplained BSV and increase in PK parameter estimate precision [15].

For model evaluation, diagnostic plots were created to evaluate the final model including observed versus individual-fitted and observed versus population-fitted polymyxin B concentrations, conditional weighted residuals versus population predicted concentration and time since last dose. To evaluate the predictive performance, the statistics of the observed and simulated time-concentration profiles were compared using prediction- and variability-corrected visual predictive check (pvcVPC) [16] and normalized prediction distribution error (NPDE) test [17]. The dataset was simulated 1000 times using the \$SIMULATION block in NONMEM $\otimes$ for pVCVPC and NPDE.

\section{Monte Carlo Simulations of Dosage Regimens}

Monte Carlo simulations were performed using the final model to identify pragmatic potential polymyxin B dose adjustments. Total daily doses of 60,80 $100,150,200 \mathrm{mg}$ with 12 hours interval were evaluated. Target values of AUC $\mathrm{ss}_{\text {, }}$ $24 \mathrm{hr}$ between $50-100 \mathrm{mg} \cdot$ hour/L was recommend by the current guidelines for the optimal use of polymyxins [12]. Probabilities of target attainment were calculated for each dosing simulated for 5000 virtual subjects with creatinine clearance ranging from 10 to $120 \mathrm{~mL} / \mathrm{min}$.

\section{Results}

\section{Baseline characteristics of patients}

Demographic data of the 32 adult patients are presented in Table 1. A large range of renal functions was observed. The $\mathrm{CrCL}$ were ranged from 9.12 to 
medRxiv preprint doi: https://doi.org/10.1101/2020.01.24.20018481; this version posted January 28, 2020. The copyright holder for this preprint (which was not certified by peer review) is the author/funder, who has granted medRxiv a license to display the preprint in perpetuity.

All rights reserved. No reuse allowed without permission.

$146.7 \mathrm{~mL} / \mathrm{min}$ in 29 patients, and 3 patients was with extremely lower serum creatinine below $35 \mu \mathrm{mol} / \mathrm{L}$. The dose of polymyxin B was $100-200 \mathrm{mg} /$ day. Most of the patients were received the drug every 12 hours.

\section{Population Pharmacokinetic Analysis}

The dataset had 112 concentrations from 32 patients. Plots of dose-normalized plasma concentrations of polymyxin B versus time since last dose are presented in Figure 1. A 1-compartment model with linear elimination showed the best fit of the observed concentration-time data based on reduction in OFV and visual inspection of diagnostic plots (Figure S1). BSV was only estimated on $\mathrm{CL}$, but not volume ( $\mathrm{V})$, in the base model, because the estimation accuracy on $\mathrm{V}$ was low. The proportional error model was selected to evaluate the residual variability. Covariate model building identified $\mathrm{CrCL}$ as the only covariate of polymyxin B CL. The plot of CrCL vs. CL of polymyxin B according to the base model is shown in Figure 2. Furthermore, there was no significant association between polymyxin B PK and age, gender, TBW, serum albumin concentration. The final PK model is shown below (Eqs. (1) and (2)).

$C L(L / h)=1.59 \times\left(\frac{C r C L}{80}\right)^{0.408}$

$V(L)=20.5$

PK parameter estimates of the final covariate-structured model were shown in Table 2.

The goodness-of-fit plot of the final model was shown in Figure 3. The scatterplots of population prediction (PRED) and individual prediction (IPRED) revealed an improvement in the final model compared with that of basic model. The conditional weighted residuals (CWRES) vs. PRED of the final model showed a stochastic distribution around zero, and most residuals were within an acceptable range (-2 to 2 ). The pvcVPC of the final model showed a good fit between the observations and simulations (Figure S2). The NPDE results were shown in Figure S3 and Table S1, which showed a good performance followed a 
medRxiv preprint doi: https://doi.org/10.1101/2020.01.24.20018481; this version posted January 28, 2020. The copyright holder for this preprint (which was not certified by peer review) is the author/funder, who has granted medRxiv a license to display the preprint in perpetuity.

All rights reserved. No reuse allowed without permission.

normal distribution. Mean (SD) individual empirical Bayesian estimates of polymyxin B CL was $1.75(0.43) \mathrm{L} / \mathrm{h}$, across all patients with $\mathrm{V}$ estimated at 20.5 L.

\section{Monte Carlo Simulation}

The $A U C_{s s, 24 h}$ ( $A U C$ from 0 to $24 \mathrm{~h}$ ) target of $50-100 \mathrm{mg} \cdot \mathrm{h} / \mathrm{L}$ is recommend as the PK/PD therapeutic target for maximization of efficacy for polymyxin B by the current consensus guidelines for the optimal use of polymyxins $[12,18]$. The lower bound of the therapeutic window was determined to be $50 \mathrm{mg} \cdot \mathrm{h} / \mathrm{L}$ using data from previously described murine thigh infection model studies [10,19-20]. The upper limit of the therapeutic window was determined to $100 \mathrm{mg} \cdot \mathrm{h} / \mathrm{L}$ based on a linear function describing the relationship between nephrotoxicity rates and polymyxin B exposures [18], in which an incidence of mild nephrotoxicity ( $\geq 25 \%$ decrease in creatinine clearance) of less than $40 \%$ was considered as the reasonable target. The simulated probability of achieving a target attainment of polymyxin $B A^{-} C_{s s, 24 h}(50-100 \mathrm{mg} \cdot \mathrm{h} / \mathrm{L})$ with various dosage regimens in patients with various $\mathrm{CrCL}_{\text {, }}$ predicted from Monte Carlo simulations, is quantified in Table S2 and showed in Figure 4. With the expectation of probability of target attainment (PTA) more than $90 \%$, the recommended dosage regimen for patients with various CrCL was presented in table 3 . The data showed that for patients with moderate renal insufficiency $(30 \leq \mathrm{CrCL}<60$ $\mathrm{mL} / \mathrm{min}$ ), the dose should decrease $33 \%$ compared with patients with normal renal function.

Without regard to the nephrotoxicity, the area under the concentration-time curve of free polymyxin $B$ to MIC ratio (fAUC/MIC) is the PK/PD index that best correlates with bacterial killing $[12,20]$. In the thigh infection model, the fAUC/MIC values for 2-log bacterial killing were approximately 20 for colistin against $P$. aeruginosa and $A$. baumannii $[21,22]$. Considering colistin and polymyxin B have similar molecular structures and in vitro activity, it is 
reasonable to conclude the $\mathrm{PK} / \mathrm{PD}$ of polymyxin $\mathrm{B}$ indices and target approach those of colistin. The protein binding of polymyxins in human plasma is $\sim 50 \%$ $[23,24]$. Sandri et al., calculated the unbound fraction of polymyxin B in plasma in 24 patients, which showed the median unbound fraction in plasma was 0.42 [10]. Therefore, we performed Monte Carlo simulations using an unbound fraction in plasma of 0.42 to evaluate the probability of different dosage regimens reaching an fAUC/MIC of approximately 20 . Only the amount of daily dose reached to $200 \mathrm{mg}$ would reach to the target when the causative pathogen MIC is $2 \mathrm{mg} / \mathrm{L}$ (Table S3 and Figure 5). However, $200 \mathrm{mg}$ daily dose would increase the risk of nephrotoxicity (Figure 4). Thus, for severe infections caused by organisms with polymyxin B MIC of $\geq 2 \mathrm{mg} / \mathrm{L}$, though a high daily dose (e.g. $200 \mathrm{mg} /$ day) would possible for bacterial eradication, the risk of nephrotoxicity is significantly increased.

\section{Discussion}

This study has made a significant contribution to understanding of how to optimize the clinical use of polymyxin B in patients with various CrCL. It is the first study to data using the real-world data from routine therapeutic drug monitoring built a population pharmacokinetics model, which showed a significant association between $\mathrm{CrCL}$ and polymyxin $\mathrm{B} C \mathrm{C}$, suggest dose reducing in patient with renal insufficiency, which is in agreement with the recommendation provided by current FDA approved package of polymyxin B. We also provide the dosage regimens for patients with various renal function according to the recommended PK/PD therapeutic target for maximization of efficacy for polymyxin B.

It was commonly recommended in the package inserts for polymyxin $B$ that the dose should be reduced in patients with renal insufficiency. However, data from several recent studies have contradicting insights refuting this recommendation $[10-11,25-26]$ that polymyxin B is not significantly eliminated by the kidneys and polymyxin B clearance does not depend on $\mathrm{CrCL}$. Therefore, the PK rational 
medRxiv preprint doi: https://doi.org/10.1101/2020.01.24.20018481; this version posted January 28, 2020. The copyright holder for this preprint (which was not certified by peer review) is the author/funder, who has granted medRxiv a license to display the preprint in perpetuity.

All rights reserved. No reuse allowed without permission.

for not adjusting doses according to renal function was concluded. More PK studies in patients with renal insufficiency are needed to validate the PK rational for not adjusting the dose in patient with renal insufficiency, which contradicts the recommendation from the package.

According to our final model, the inclusion of $\mathrm{CrCL}$ significantly improved the goodness-of-fit of the model. The data used for Pop PK analysis included 15 patients with normal renal function (estimated creatinine clearance $(\mathrm{CrCL}) \geq 80 \mathrm{~mL} / \mathrm{min})$ at baseline and 17 patients with renal insufficiency $(\mathrm{CrCL}<$ $80 \mathrm{~mL} / \mathrm{min})$. The creatinine clearance in patients was $5.91-244 \mathrm{~mL} / \mathrm{min}$, in which 3 patients was with extremely lower serum creatinine below $35 \mu \mathrm{mol} / \mathrm{L}$. Therefore, the percentage of patients with or without renal insufficiency is similar, while the distribution of renal function was extensive in this study. In accordance with our results, Avedissian and colleagues [27] found a potential relationship between the CrCL and polymyxin B CL in 9 cystic fibrosis patients, which was best described via a Hill function. In addition, polymyxin B's proposed mechanisms of elimination involve both renal (via renal tubular reabsorption) and non-renal pathways. The potential reason for the lower total clearance of polymyxin B in patients with renal insufficiency might be that the glomerular filtration function in these patients is impaired, which caused reduced amount of polymyxin B being filtrated.

Despite the renewed interest in polymyxin B used for treatment of multidrug resistant Gram-negative bacteria, the optimal dosage strategy is still unclear because they are primarily based on population pharmacokinetics. The packages insert for polymyxin B recommended initial dosing polymyxin B via intravenous way at $1.5-2.5 \mathrm{mg} / \mathrm{kg} / \mathrm{d}$, divided into two doses [13]. The data of Monte Carlo simulation showed that for patients with moderate renal insufficiency ( $30 \leq \mathrm{CrCL}<60 \mathrm{~mL} / \mathrm{min}$ ), the dose should decrease $33 \%$ compared with patients with normal renal function. Therefore, physicians should balance the risk of polymyxin B-induced nephrotoxicity against the benefit of adequate doses of polymyxin B in patients with declining renal function. In addition, when 
the causative pathogen MIC is $2 \mathrm{mg} / \mathrm{L}$, though dosage regimen of $100 \mathrm{mg} \mathrm{q} 12 \mathrm{~h}$ could reach an fAUC/MIC more than 20 at steady state, the risk of nephrotoxicity was incredibly increased. For pathogens with MICs of $2 \mathrm{mg} / \mathrm{L}$, only a very small proportion of patients will reach the therapeutic target of $\operatorname{AUC}_{\mathrm{ss}, 24 \mathrm{~h}}(50-100 \mathrm{mg} \cdot \mathrm{h} / \mathrm{L})$.

A potential limitation of our study was the data that used for PK analysis was retrospectively collected, despite the time of dosing and sampling were precisely recorded. In addition, though the relation between renal function and polymyxin B CL was quantificationally studied, the confirmation of urinary excretion of polymyxin B should be further investigated.

In conclusion, this is the first study to demonstrate that the $\mathrm{CrCL}$ is a patient characteristic that influences polymyxin B PK and provide the dosage regimens for patients with various renal function according to the therapeutic target of AUCss,24h (50-100 mg.h/L). Dose reducing downward of polymyxin B according to $\mathrm{CrCL}$ is recommended for individuals with renal insufficiency. In addition, for severe infections caused by organisms with polymyxin B MIC $\geq 2$ $\mathrm{mg} / \mathrm{L}$, though a high daily dose (e.g. $200 \mathrm{mg} /$ day) would possible for bacterial eradication, the risk of nephrotoxicity is significantly increased.

\section{Acknowledgements}

The contents of the manuscript are solely the responsibility of the authors and all authors have no actual or potential conflicts of interest to report.

\section{References}

[1] Ryan KJ, Schainuck LI, Hickman RO, Striker GE. 1969. Colistimethate toxicity. Report of a fatal case in a previously healthy child. JAMA. 207(11):2099-101.

[2] Koch-Weser J, Sidel VW, Federman EB, Kanarek P, Finer DC, Eaton AE. 1970. Adverse effects of sodium colistimethate. Manifestations and specific reaction rates during 317 courses of therapy. Ann Intern Med. 72(6):857-68. 
[3] Li J, Nation RL, Turnidge JD, Milne RW, Coulthard K, Rayner CR, Paterson DL. 2006. Colistin: the re-emerging antibiotic for multidrug-resistant Gram-negative bacterial infections. Lancet Infect Dis. 6(9): 589-601.

[4] Zavascki AP, Goldani LZ, Li J, Nation RL. 2007. Polymyxin B for the treatment of multidrug-resistant pathogens: a critical review. J Antimicrob Chemother. $60(6): 1206-15$.

[5] Falagas ME, Kasiakou SK. 2005. Colistin: the revival of polymyxins for the management of multidrug-resistant gram-negative bacterial infections. Clin Infect Dis. 40(9): 1333-41.

[6] Landman D, Georgescu C, Martin DA, Quale J. 2008. Polymyxins revisited. Clin Microbiol Rev. 21(3):449-65.

[7] Bergen PJ, Li J, Rayner CR, Nation RL. 2006. Colistin methanesulfonate is an inactive prodrug of colistin against Pseudomonas aeruginosa. Antimicrob Agents Chemother. 50(6): 1953-8.

[8] Kassamali Z, Danziger L. 2015. To B or not to B, that is the question: is it time to replace colistin with polymyxin B? Pharmacotherapy. 35(1):17-21. doi: 10.1002/phar. 1510.

[9] Phe K, Lee Y, McDaneld PM, Prasad N, Yin T, Figueroa DA, Musick WL, Cottreau JM, Hu M, Tam VH. 2014. Antimicrob Agents Chemother. 58(5):2740-6. doi: $10.1128 /$ AAC.02476-13.

[10] Sandri AM, Landersdorfer CB, Jacob J, Boniatti MM, Dalarosa MG, Falci DR, Behle TF, Bordinhão RC, Wang J, Forrest A, Nation RL, Li J, Zavascki AP. 2013. Population pharmacokinetics of intravenous polymyxin B in critically ill patients: implications for selection of dosage regimens. Clin Infect Dis. 57(4):524-31. doi: 10.1093/cid/cit334.

[11] Zavascki AP, Goldani LZ, Cao G, Superti SV, Lutz L, Barth AL, Ramos F, Boniatti MM, Nation RL, Li J. 2008. Pharmacokinetics of intravenous polymyxin $B$ in critically ill patients. Clin Infect Dis. 47(10):1298-304. doi: $10.1086 / 592577$.

[12] Tsuji BT, Pogue JM, Zavascki AP, Paul M, Daikos GL, Forrest A, Giacobbe DR, 
Viscoli C, Giamarellou H, Karaiskos I, Kaye D, Mouton JW, Tam VH, Thamlikitkul V, Wunderink RG, Li J, Nation RL, Kaye KS. 2019. International Consensus Guidelines for the Optimal Use of the Polymyxins: Endorsed by the American College of Clinical Pharmacy (ACCP), European Society of Clinical Microbiology and Infectious Diseases (ESCMID), Infectious Diseases Society of America (IDSA), International Society for Anti-infective Pharmacology (ISAP), Society of Critical Care Medicine (SCCM), and Society of Infectious Diseases Pharmacists (SIDP). Pharmacotherapy. 39(1):10-39. doi: 10.1002/phar.2209.

[13] Polymyxin B [package insert]. Big Flats, NY: Xellia Pharmaceuticals; 2015. [14] Meng M, Wang L, Liu S, Jaber OM, Gao L, Chevrette L, Reuschel S. 2016. Simultaneous quantitation of polymyxin B1, polymyxin B2 and polymyxin B1-1 in human plasma and treated human urine using solid phase extraction and liquid chromatography-tandem mass spectrometry. J Chromatogr B Analyt Technol Biomed Life Sci. 1012-1013:23-36. doi: 10.1016/j.jchromb.2016.01.013.

[15] Mandema JW, Verotta D, Sheiner LB. 1992. Building population pharmacokinetic-pharmacodynamic models. I. Models for covariate effects. J Pharmacokinet Biopharm 20:511-528. https://doi.org/10.1007/BF01061469. [16] Bergstrand M, Hooker AC, Wallin JE, Karlsson MO. Prediction-corrected visual predictive checks for diagnosing nonlinear mixed-effects models. AAPS J. 13(2): 143-51. doi: 10.1208/s12248-011-9255-z.

[17] Yano Y, Beal SL, Sheiner LB. 2001. Evaluating pharmacokinetic/pharmacodynamic models using the posterior predictive check. J Pharmacokinet Pharmacodyn. 28(2):171-92.

[18] Lakota EA, Landersdorfer CB, Nation RL, Li J, Kaye KS, Rao GG, Forrest A. 2018. Personalizing Polymyxin B Dosing Using an Adaptive Feedback Control Algorithm. Antimicrob Agents Chemother. 62(7). pii: e00483-18. doi: 10.1128/AAC.00483-18.

[19] Cheah SE, Wang J, Nguyen VT, Turnidge JD, Li J, Nation RL. 2015. New pharmacokinetic/pharmacodynamic studies of systemically administered 
colistin against Pseudomonas aeruginosa and Acinetobacter baumannii in mouse thigh and lung infection models: smaller response in lung infection. J Antimicrob Chemother 70:3291-3297. https://doi.org/10.1093/jac/dkv267. [20] Landersdorfer CB, Wang J, Wirth V, Chen K, Kaye KS, Tsuji BT, Li J, Nation RL. 2018. Pharmacokinetics/pharmacodynamics of systemically administered polymyxin B against Klebsiella pneumoniae in mouse thigh and lung infection models. J Antimicrob Chemother 73:462-468. https://doi .org/10.1093/jac/dkx409.

[21] Dudhani RV 1, Turnidge JD, Coulthard K, Milne RW, Rayner CR, Li J, Nation RL. 2010. Elucidation of the pharmacokinetic/pharmacodynamic determinant of colistin activity against Pseudomonas aeruginosa in murine thigh and lung infection models. Antimicrob Agents Chemother. 54(3):1117-24. doi: 10.1128/AAC.01114-09.

[22] Dudhani RV, Turnidge JD, Nation RL, Li J. 2010. fAUC/MIC is the most predictive pharmacokinetic/pharmacodynamic index of colistin against Acinetobacter baumannii in murine thigh and lung infection models. ] Antimicrob Chemother. 65(9):1984-90. doi: 10.1093/jac/dkq226.

[23] Nation RL, Garonzik SM, Thamlikitkul V, Giamarellos-Bourboulis EJ, Forrest A, Paterson DL, Li J, Silveira FP. 2017. Dosing guidance for intravenous colistin in critically-ill patients. Clin Infect Dis. 64(5):565-571. doi: 10.1093/cid/ciw839.

[24] Ly NS, Yang J, Bulitta JB, Tsuji BT. 2012. Impact of two-component regulatory systems PhoP-PhoQ and PmrA-PmrB on colistin pharmacodynamics in Pseudomonas aeruginosa. Antimicrob Agents Chemother. 56(6):3453-6. doi: 10.1128/AAC.06380-11.

[25] Thamlikitkul V, Dubrovskaya $Y$, Manchandani $P$, Ngamprasertchai $T$, Boonyasiri A, Babic JT, Tam VH. 2016. Dosing and Pharmacokinetics of Polymyxin B in Patients with Renal Insufficiency. Antimicrob Agents Chemother. 61(1). pii: e01337-16. doi: 10.1128/AAC.01337-16.

[26] Kwa AL, Abdelraouf K, Low JG, Tam VH. 2011. Pharmacokinetics of 
medRxiv preprint doi: https://doi.org/10.1101/2020.01.24.20018481; this version posted January 28, 2020. The copyright holder for this preprint (which was not certified by peer review) is the author/funder, who has granted medRxiv a license to display the preprint in perpetuity.

All rights reserved. No reuse allowed without permission.

polymyxin B in a patient with renal insufficiency: a case report. Clin Infect Dis. 52(10): 1280-1. doi: $10.1093 /$ cid/cir137.

[27] Oliveira MS, Prado GV, Costa SF, Grinbaum RS, Levin AS. 2009. Polymyxin

$B$ and colistimethate are comparable as to efficacy and renal toxicity. Diagn

Microbiol Infect Dis. 65(4):431-4. doi: 10.1016/j.diagmicrobio. 
Table 1. Patient Characteristics

\begin{tabular}{lc}
\hline Characteristic & Value $^{\mathbf{a}}$ \\
\hline Age (years) & $63.63(12.92)$ \\
Sex & \\
$\quad$ Male & $26(82.25 \%)$ \\
$\quad$ Female & $6(18.75 \%)$ \\
Height $(\mathrm{cm})$ & $167.97(6.69)$ \\
Total body weight $(\mathrm{kg})$ & $61.73(11.77)$ \\
CrCL (mL/min) & $86.58(53.00)$ \\
Serum albumin $(\mathrm{g} / \mathrm{L})$ & $30.15(5.76)$ \\
Serum creatinine $(\mu \mathrm{mol} / \mathrm{L})$ & $116.69(127.60)$ \\
\hline
\end{tabular}

Abbreviations: $\mathrm{CrCL}$, estimated creatinine clearance ( $\mathrm{CrCL}$ ) calculated using the Cockcroft-Gault equation

${ }^{a}$ Values are mean (standard deviation) or No. (\%) 
Table 2 Population pharmacokinetic parameter estimates from the final model

\begin{tabular}{llll}
\hline Parameter & Estimate & RSE \% & shrinkage \\
\hline
\end{tabular}

Fixed Effects

$\operatorname{TVCL}\left(\theta_{1}\right)$

$1.59 \quad 5.1$

$\mathrm{CrCL}$ on $\mathrm{CL}\left(\theta_{2}\right)$

0.408

18.7

$\mathrm{V}\left(\theta_{3}\right)$

20.5

11.6

Between-subject

Variability (BSV)

BSV CL

$13 \%$

59.7

$38 \%$

\section{Residual Variability (RV)}

Proportional Error

40.5

18.2

$4 \%$
a. BSV calculated as $\sqrt{e^{\omega^{2}}-1}$
CL covariate structure:
$C L\left(\frac{L}{h}\right)=T V C L \times\left(\frac{C r C L}{80}\right)^{\theta_{2}}$ 
medRxiv preprint doi: https://doi.org/10.1101/2020.01.24.20018481; this version posted January 28, 2020. The copyright holder for this preprint (which was not certified by peer review) is the author/funder, who has granted medRxiv a license to display the preprint in perpetuity.

All rights reserved. No reuse allowed without permission.

Table 3 Recommendation of dosage regimen for patients with various patients (for $M I C=1 \mathrm{mg} / L$ )

\begin{tabular}{ll}
\hline CrCL (mL/min) & Dosage Reg \\
\hline$<=20$ & $30 \mathrm{mg} \mathrm{q12h}$ \\
$20-30$ & $40 \mathrm{mg} \mathrm{q12h}$ \\
$30-70$ & $50 \mathrm{mg} \mathrm{q12h}$ \\
$70-120$ & $75 \mathrm{mg} \mathrm{q12h}$ \\
\hline
\end{tabular}


medRxiv preprint doi: https://doi.org/10.1101/2020.01.24.20018481; this version posted January 28, 2020. The copyright holder for this preprint (which was not certified by peer review) is the author/funder, who has granted medRxiv a license to display the preprint in perpetuity.

Figure 1 All rights reserved. No reuse allowed without permission.

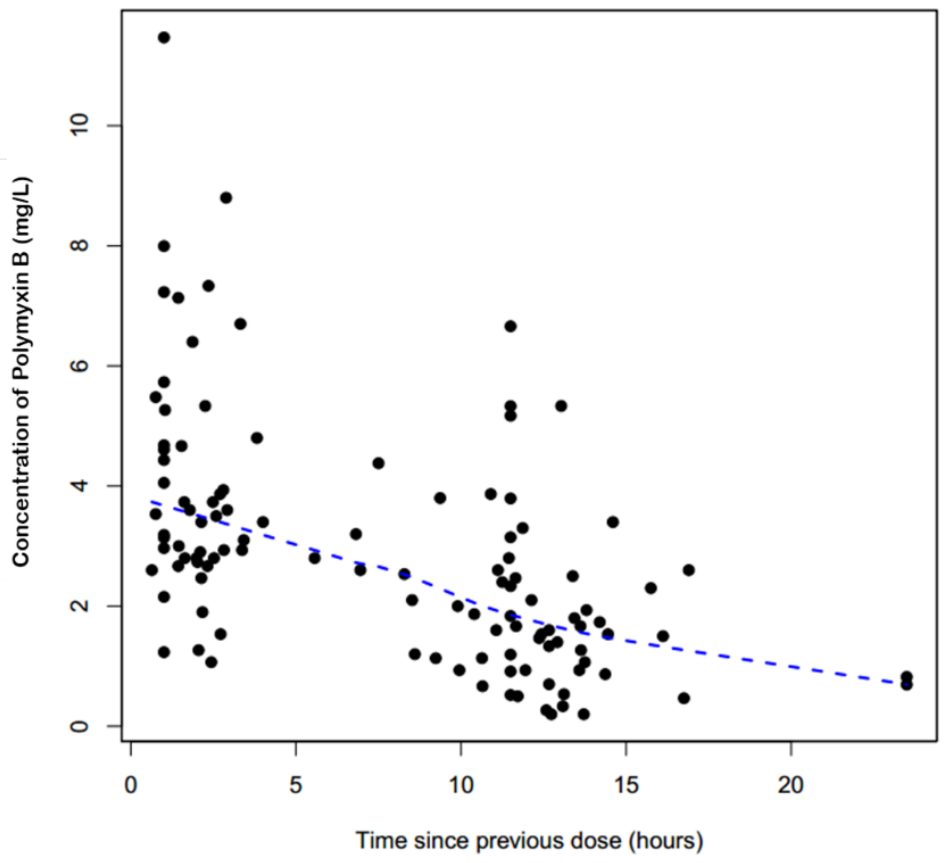

Figure 1. Dose-normalized serum concentration-time profiles of polymyxin $B$ in patients. 
medRxiv preprint doi: https://doi.org/10.1101/2020.01.24.20018481; this version posted January 28, 2020. The copyright holder for this preprint (which was not certified by peer review) is the author/funder, who has granted medRxiv a license to display the preprint in perpetuity.

Figure 2 All rights reserved. No reuse allowed without permission.

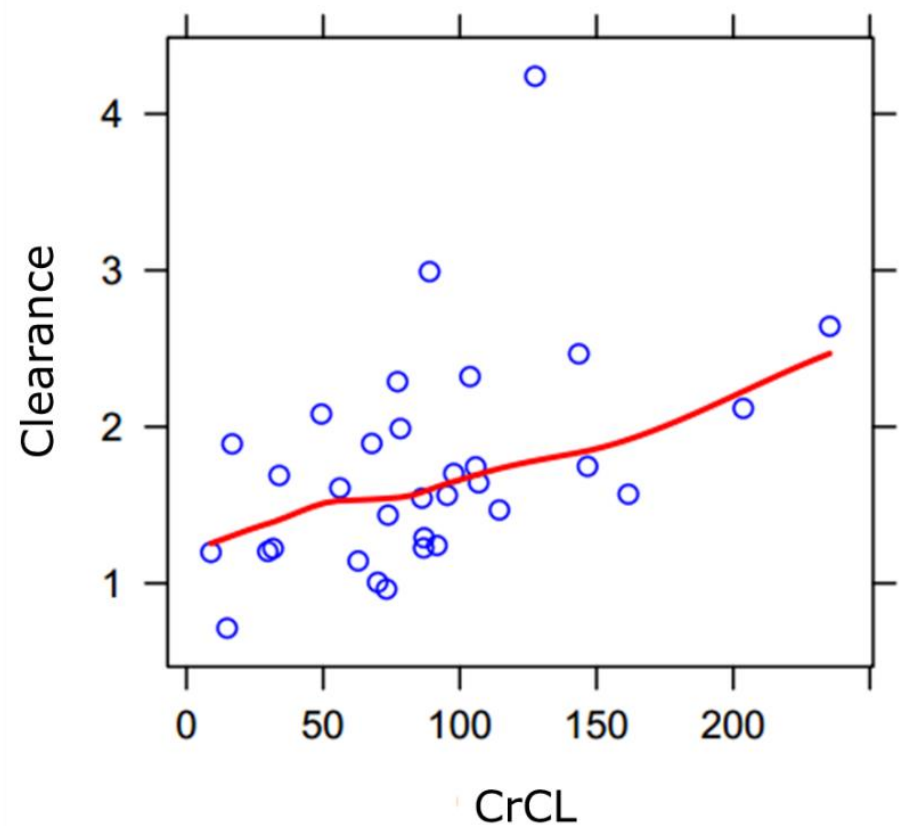

Figure 2. Individual polymyxin $B$ clearance estimates versus creatinine clearance $(\mathrm{CrCL})$. 
medRxiv preprint doi: https://doi.org/10.1101/2020.01.24.20018481; this version posted January 28, 2020. The copyright holder for this preprint (which was not certified by peer review) is the author/funder, who has granted medRxiv a license to display the preprint in perpetuity.

Figure 3 All rights reserved. No reuse allowed without permission.
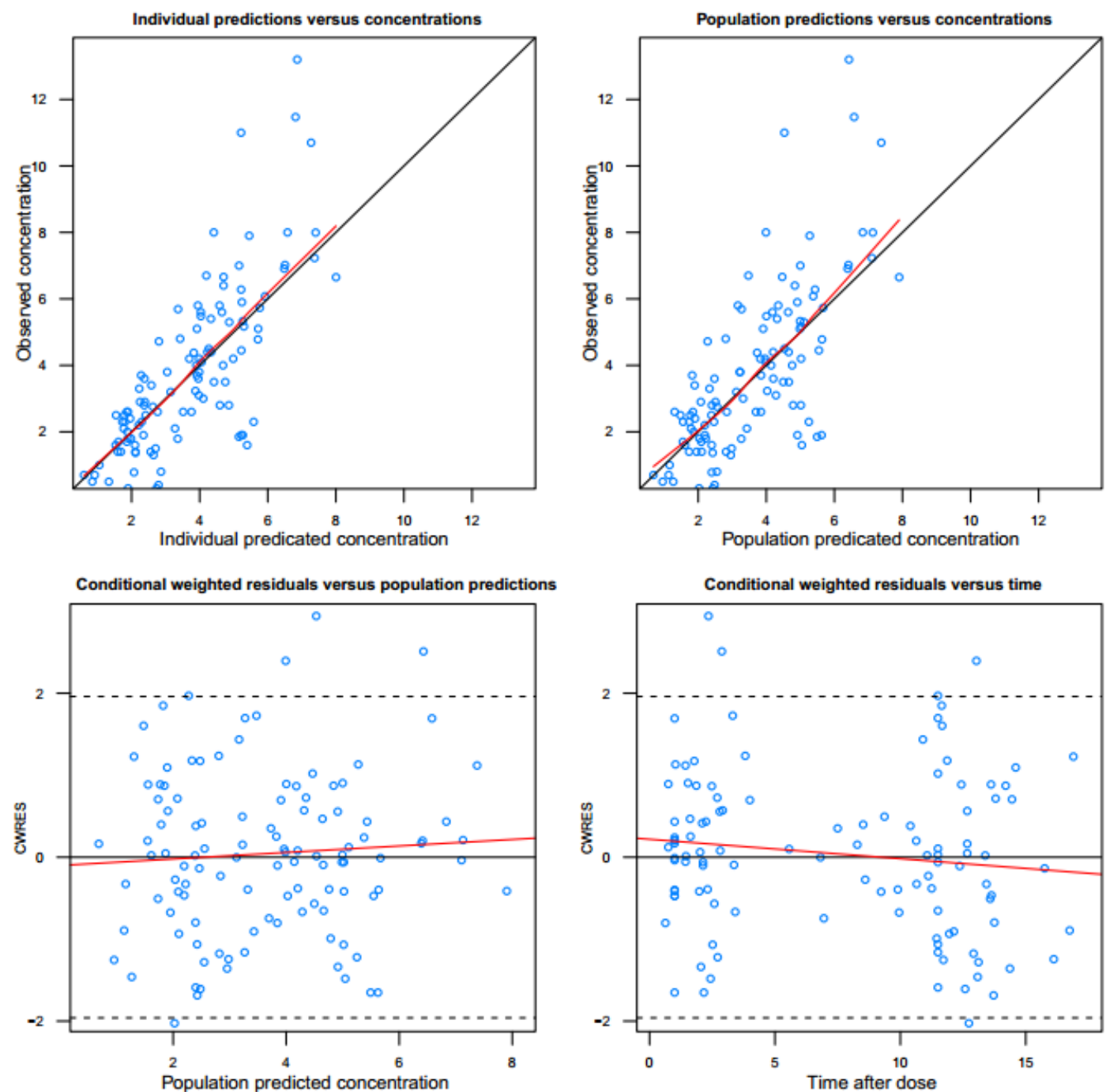

Figure 3. Diagnostic goodness-of-fit plots of the final model. a Observed concentration (DV) vs. individual predicted concentration (IPRED); b DV vs. population predicted concentration (PRED); c conditional weighted residuals (CWRES) vs. PRED; and d CWRES vs. time. The red lines in the upper panel represent loess smooth lines and linear fit lines, respectively. 
medRxiv preprint doi: https://doi.org/10.1101/2020.01.24.20018481; this version posted January 28, 2020. The copyright holder for this preprint (which was not certified by peer review) is the author/funder, who has granted medRxiv a license to display the preprint in perpetuity.

Figure 4 All rights reserved. No reuse allowed without permission.

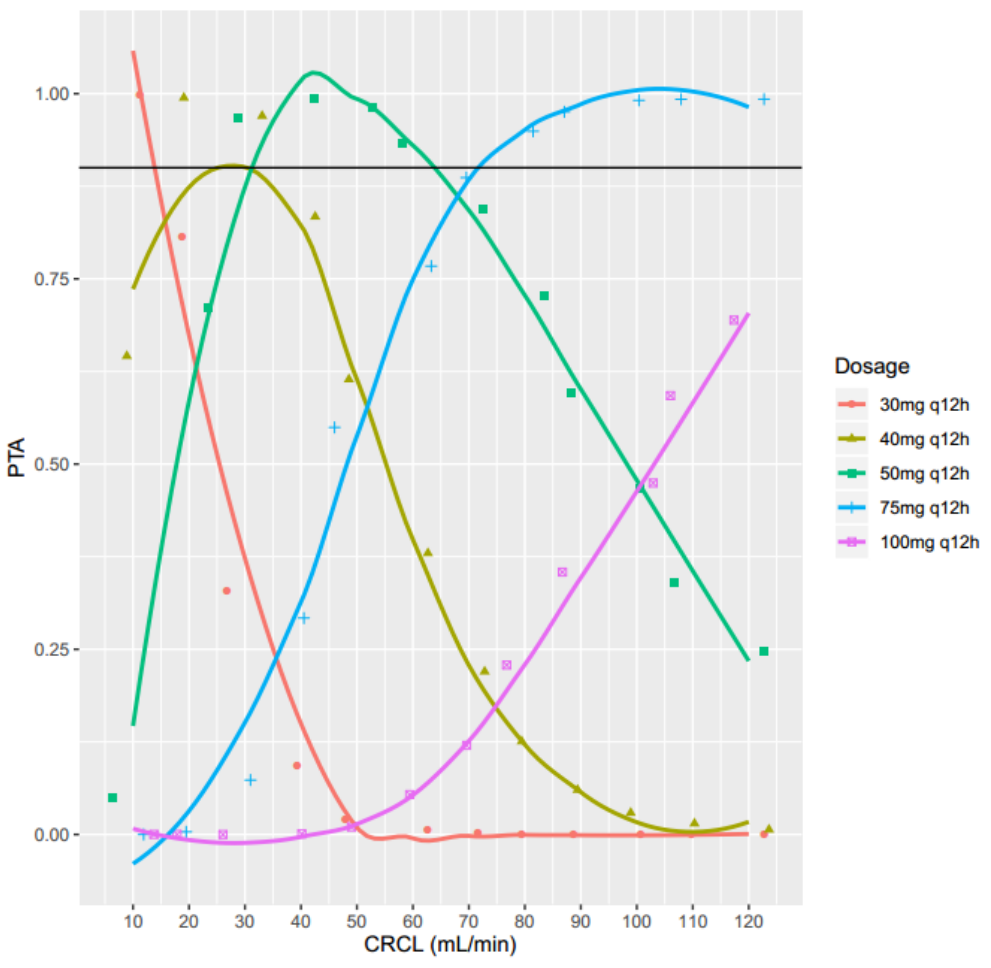

Figure 4. The simulated probability of achieving a target attainment of polymyxin $B$ AUCss,24h $(50-100 \mathrm{mg} \cdot \mathrm{h} / \mathrm{L})$ with various dosage regimens in patients with various CrCL. 
medRxiv preprint doi: https://doi.org/10.1101/2020.01.24.20018481; this version posted January 28, 2020. The copyright holder for this preprint (which was not certified by peer review) is the author/funder, who has granted medRxiv a license to display the preprint in perpetuity.

Figure 5
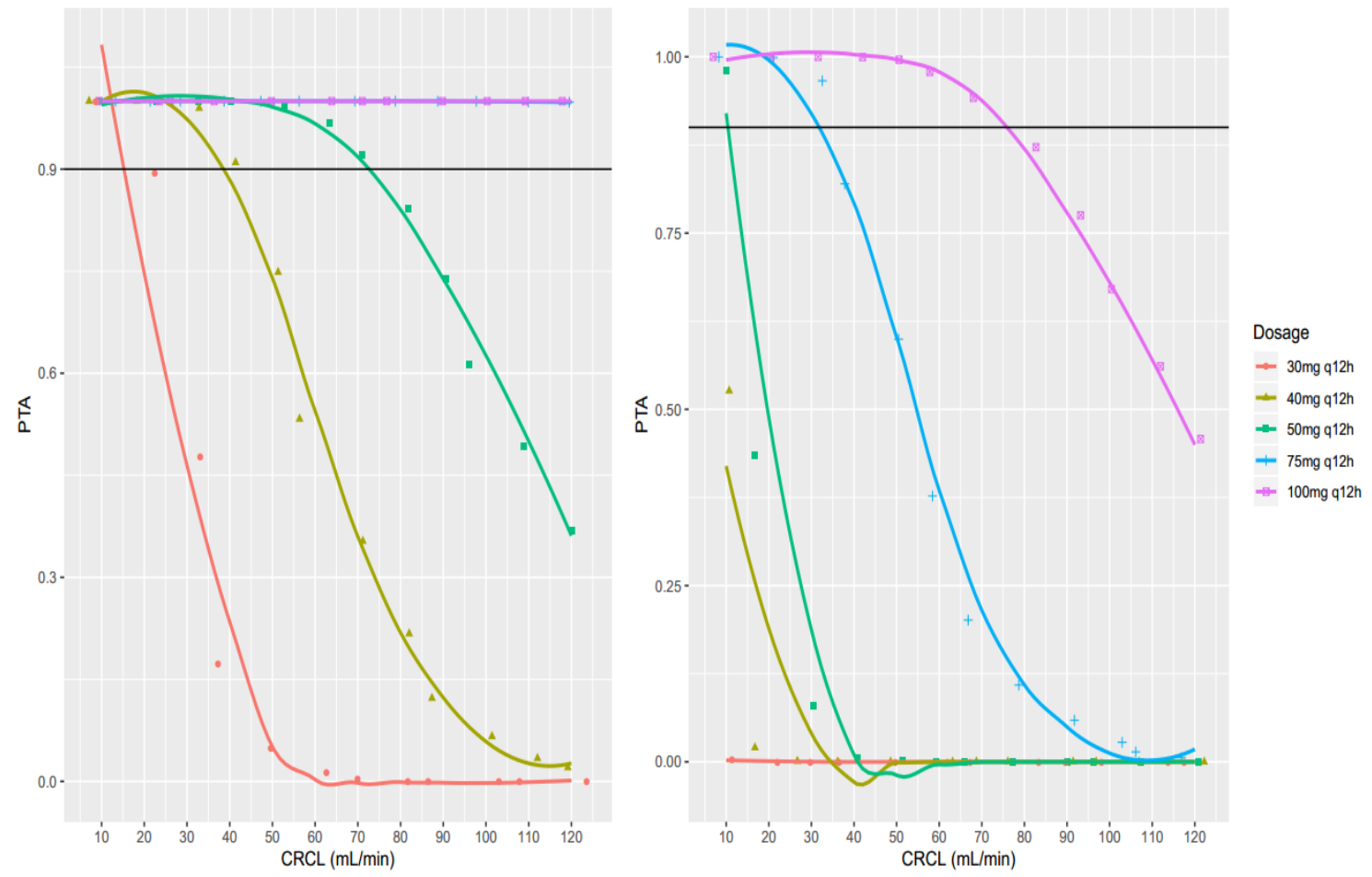

Figure 5. The simulated probability of achieving a target attainment of polymyxin $B$ fAUC $s s, 24 \mathrm{~h} / M I C \geq 20$ (MIC=1 mg/L (left), MIC=2 mg/L (right)) with various dosage regimens in patients with various CrCL. 